\title{
Density of the Near Threatened jaguar Panthera onca in the caatinga of north-eastern Brazil
}

\author{
Leandro Silveira, Anah T. A. Jácomo, Samuel Astete, Rahel Sollmann \\ Natélia M. Tôrres, Mariana M. Furtado and Jader Marinho-Filho
}

\begin{abstract}
We report the first estimate of jaguar density in the semi-arid caatinga biome of north-eastern Brazil. During August-October 2007, in the Serra da Capivara National Park, we used camera traps to identify and count jaguars. Jaguar abundance and density were calculated using markrecapture models. In a sampling effort of 1,249 camera-trapnights we identified 12 adult jaguars and estimated an abundance of $14 \pm$ SE 3.6 jaguars in an area of $524 \mathrm{~km}^{2}$, i.e. a density of $2.67 \pm$ SE 1.00 jaguars per $100 \mathrm{~km}^{2}$. This estimate is higher than in most other Brazilian biomes and indicates Serra da Capivara National Park as an important reserve for protecting jaguars in north-eastern Brazil.
\end{abstract}

Keywords Brazil, caatinga, camera trap, density, jaguar, Panthera onca, Serra da Capivara National Park

\section{Introduction}

7 he jaguar Panthera onca is the largest felid in the 1 Americas and is categorized on the IUCN Red List as Near Threatened (Caso et al., 2008). Although the jaguar's distribution has been reduced by more than $50 \%$ within the past century (Seymour, 1989; Sanderson et al., 2002), it still ranges from New Mexico and Arizona in the USA to the north of Argentina, occurring in a variety of environments but with the remaining populations facing varying prospects of long-term survival.

Top predators such as the jaguar play an important role in the ecosystems in which they occur (Terborgh et al., 1999), limiting the number of herbivores and thereby reducing the pressure they exert on plants (Terborgh, 1988; Miller et al., 2001). This top-down regulation by predators

LeAndro Silveira (Corresponding author), Anah T. A. Jácomo, Samuel Astete $^{*}$, Rahel Sollmann ${ }^{\dagger}$, Natália M. Tôrres ${ }^{\S}$ and Mariana M. FurTAdO Jaguar Conservation Fund/Instituto Onça-Pintada, CP 193 CEP 75830-000, Mineiros, Goiás, Brazil. E-mail l.silveira@jaguar.org.br

Jader Marinho-Filho Department of Zoology, University of Brasília, Brasília, Brazil.

*Also at: University of Brasília, Brasília, Brazil.

${ }^{\dagger}$ Also at: Leibniz Institute for Zoo and Wildlife Research, Berlin, Germany.

${ }^{\S}$ Also at: Federal University of Goiás, Goiânia, Brazil.

`Also at: University of São Paulo, São Paulo, Brazil.

Received 4 September 2008. Revision requested 12 November 2008. Accepted 27 January 2009. maintains diversity, and their removal reduces species richness and increases populations of some species of smalland medium-sized carnivores and omnivores (Fonseca \& Robinson, 1990; Terborgh et al., 1997; Miller et al., 2001; Ripple \& Beschta, 2006). Jaguars are sensitive to human disturbance and require large tracts of habitat (Weber \& Rabinowitz, 1996). This may explain why, although widely distributed in Brazil, viable jaguar populations are mostly restricted to large protected areas (Silveira \& Jácomo, 2002).

Although estimation of density is a basic requirement for assessing the status of a population, jaguar densities have been little studied in Brazil. The 36 parks and other protected areas in the $800,000 \mathrm{~km}^{2}$ caatinga, the country's third largest biome, comprise $7.1 \%$ of the total area but only $1.21 \%$ of the area is under integral protection (Capobianco, 2002). The environmental conditions of this biome (high temperatures, poor soil fertility and a short rainy season) do not favour large-scale agriculture. Nevertheless, an estimated $30 \%$ of the caatinga has been altered by man, especially for agriculture (MMA, 2005). However, hunting of native wildlife appears to be a major threat to many game species and top predators inhabiting this biome (Leat et al., 2005).

We used a camera-trap survey to identify jaguars and used mark-recapture models (Karanth \& Nichols, 1998) to obtain the first estimate of jaguar density in one of the caatinga's most important National Parks.

\section{Study area}

The 129,140 ha Serra da Capivara National Park is in the south of the state of Piauí, north-east Brazil (Fig. 1). Temperatures are $12-45^{\circ} \mathrm{C}$, the rainy season is from October to April (Emperaire, 1984), and mean total annual precipitation is $644 \mathrm{~mm}$ (SMAPR, 1994). Eight habitat types have been described for the Park but a 6- to 10-m-tall shrubby vegetation predominates (Emperaire, 1984). Altitude is $280-600 \mathrm{~m}$ and the topography consists of a main plateau bounded by $50-$ to $200-\mathrm{m}$ cliffs and dissected by valleys and canyons. There is no natural permanent water within the Park but a system of artificial waterholes has been constructed in the past 15 years. The area surveyed comprises the southern and central portions of the Park and consists primarily of high shrubby caatinga vegetation with patches of low caatinga and dense shrubby to arboreal caatinga vegetation (Fig. 1). 


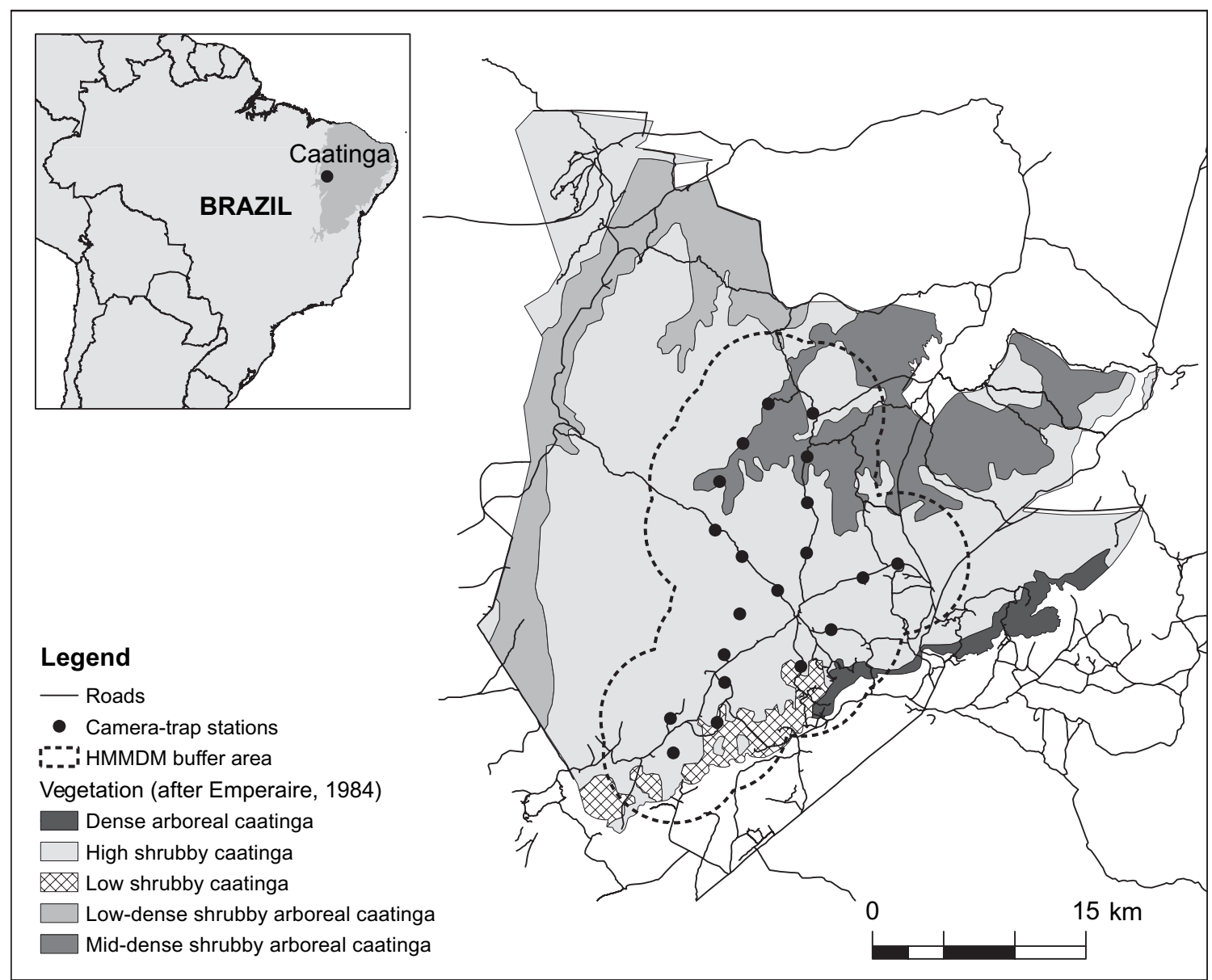

FIG. 1 Location of camera-trap stations and the half of the mean maximum distance moved buffer (HMMDM; see text for details) in the Serra da Capivara National Park, with the major vegetation types. The inset indicates the location of the Park in the caatinga, north-east Brazil.

\section{Methods}

The pattern of spots on a jaguar's coat allows the identification of individuals in photographs (Wallace et al., 2003; Maffei et al., 2004; Silver, 2004; Silver et al., 2004; Soisalo \& Cavalcanti, 2006). Photographs also allow the identification of gender (Silver et al., 2004). From August to October 2007 we set 20 survey stations, each consisting of two cameras facing each other so as to obtain simultaneous photographs of both sides of any passing jaguars. Camera stations were placed along Park roads, each station a maximum of $3.4 \mathrm{~km}$ from the nearest other station (mean distance $=2.9 \pm \mathrm{SD}$ $0.4 \mathrm{~km}$; Fig. 1), ensuring that within the sampled area camera trap coverage left no gaps greater than $10 \mathrm{~km}^{2}$. This value is based on the smallest home range recorded for jaguars and is used to attempt to ensure that all individuals are potentially exposed to camera traps (Silver, 2004; Silver et al., 2004). We used passive-sensor Camtrakker (CamTrack South Inc., Watkinsville, USA) camera traps model Original $35 \mathrm{~mm}$, activated by heat and motion. Cameras were set to photograph during day and night, with a 5-minute delay between photos. They were checked at 15-day intervals for replacement of film and batteries. As we used two cameras per station and checked them regularly, sampling gaps were rare. However, where gaps occurred because of a malfunction or because film or battery finished, the respective number of days was not considered in the calculation of effort.

Jaguar abundance was estimated using the mark-recapture models implemented in CAPTURE (Otis et al., 1978; Rexstad \& Burnham, 1991). This method assumes that individuals can be identified to determine whether they have been captured and recaptured. To obtain individual capture histories we identified jaguars from their unique spot patterns and divided the trapping period into 14 trapping sessions of 6 days each, noting when each identified individual was captured (Table 1). The duration of 6 days minimized sessions with zero captures to increase capture probability, thus meeting the recommendations of Otis et al. (1978) of a minimum capture probability of 0.1 while simultaneously maximizing the number of recaptures.

CAPTURE includes a series of closed population models, which assume that during the study period no recruitment (birth or immigration) or loss (deaths or emigrations) of 
TABle 1 Capture histories of the 12 jaguars Panthera onca identified in the Serra da Capivara National Park (Fig. 1) in 2007, during a camera-trapping study (individual 4 was a cub and is not included here or in the density estimates). An entry of 1 indicates capture of the individual on the respective 6-day trapping occasion.

\begin{tabular}{|c|c|c|c|c|c|c|c|c|c|c|c|c|c|c|}
\hline \multirow[b]{2}{*}{ Individual } & \multicolumn{14}{|c|}{ Occasion } \\
\hline & 1 & 2 & 3 & 4 & 5 & 6 & 7 & 8 & 9 & 10 & 11 & 12 & 13 & 14 \\
\hline 1 & 0 & 0 & 0 & 0 & 0 & 0 & 0 & 1 & 0 & 0 & 0 & 1 & 1 & 1 \\
\hline 2 & 1 & 0 & 0 & 1 & 1 & 0 & 1 & 1 & 0 & 1 & 1 & 1 & 0 & 1 \\
\hline 3 & 0 & 1 & 1 & 0 & 0 & 0 & 0 & 0 & 0 & 1 & 1 & 1 & 0 & 1 \\
\hline 5 & 1 & 0 & 0 & 1 & 1 & 0 & 1 & 0 & 1 & 0 & 1 & 0 & 1 & 1 \\
\hline 6 & 0 & 1 & 1 & 1 & 1 & 1 & 1 & 0 & 1 & 1 & 1 & 1 & 0 & 0 \\
\hline 7 & 0 & 0 & 0 & 0 & 0 & 0 & 0 & 0 & 0 & 0 & 0 & 1 & 0 & 0 \\
\hline 8 & 0 & 1 & 0 & 1 & 0 & 0 & 0 & 0 & 0 & 0 & 1 & 1 & 0 & 0 \\
\hline 9 & 0 & 1 & 0 & 0 & 1 & 1 & 0 & 1 & 0 & 0 & 0 & 1 & 0 & 1 \\
\hline 10 & 0 & 0 & 0 & 0 & 0 & 0 & 0 & 1 & 0 & 0 & 0 & 0 & 0 & 0 \\
\hline 11 & 0 & 0 & 0 & 0 & 0 & 0 & 0 & 0 & 0 & 0 & 0 & 1 & 0 & 0 \\
\hline 12 & 0 & 0 & 0 & 0 & 0 & 0 & 0 & 0 & 0 & 0 & 0 & 1 & 0 & 0 \\
\hline 13 & 0 & 0 & 0 & 0 & 0 & 0 & 0 & 0 & 0 & 0 & 0 & 1 & 0 & 0 \\
\hline
\end{tabular}

individuals occurs (White et al., 1982; Wilson \& Anderson, 1985). A test for population closure is implemented in CAPTURE. For jaguars a maximum sampling period of $2-3$ months is recommended to meet this assumption (Silver, 2004). We used 2.5 months. Considering that jaguars have a slow reproductive cycle and are territorial (Seymour, 1989), we believe that this duration is a reasonable approximation of population closure.

The models in CAPTURE consider various sources of variation in capture probability for an individual in a single trapping occasion: time, a behavioural response to trapping (i.e. differences in first capture and recapture), individual heterogeneity, and combinations of these sources. The software has a discriminate function procedure that selects the most appropriate model for the data based on a number of goodness-of-fit and between model tests.

To assess jaguar density the estimated abundance was divided by the effective sampled area, which contains the area defined by the camera traps and a buffer around this polygon. The objective of this buffer was to include individuals whose home ranges are only partially contained within the sampled area (Silver, 2004). Buffer width was calculated as half of the mean maximum distance moved (HMMDM) between multiple captures of individuals during the survey period (Wilson \& Anderson, 1985). Soisalo \& Cavalcanti (2006) suggested that using HMMDM potentially overestimates jaguar densities and that using the full mean maximum distance moved (MMDM) may be more realistic. There is no consensus on which distance to use and both are ad hoc approaches made necessary by the absence of independent movement data. As most jaguar studies use HMMDM we focus our interpretation, for comparative purposes, on HMMDM-based results. How- ever, we also present density estimates using MMDM for buffer calculation.

\section{Results}

Between August and October 2007 we accumulated a sampling effort of 1,249 camera-trap nights. A total of 77 jaguar photographs were obtained and 12 different adult individuals were identified (Table 1). Capture frequencies were 1-17 times and the gender of 10 individuals could be determined (four females and six males), i.e. a female:male ratio of 1:1.4. Melanic jaguars comprised $33 \%$ of individuals identified $(n=4)$. Melanic jaguars were identified individually by scars and by their spot pattern, which can be observed if the individual is sufficiently close to the camera trap that the flashlight reveals the rosettes against the dark background coat colour.

CAPTURE results suggested a closed population $(z=$ $0.123, \mathrm{P}=0.549$ ) and recommended the model $\mathrm{M}_{\mathrm{b}}$ as the best population estimator. CAPTURE calculated a capture probability $(p)$ of 0.118 and a recapture probability $(c)$ of 0.426 . The abundance estimate $(N)$ was $14 \pm$ SE 3.643 , with a confidence interval of $13-33$. For the buffer calculation eight jaguars captured more than once were considered. These individuals were registered by at least two cameratrap stations and their HMMDM was $4.95 \pm$ SD $1.93 \mathrm{~km}^{2}$. Based on this buffer the effective sampled area was $524 \pm$ SD $157 \mathrm{~km}^{2}$, which resulted in a density estimate of $2.67 \pm \mathrm{SE}$ 1.06 individuals per $100 \mathrm{~km}^{2}$. For comparison, using the MMDM of $9.90 \pm S D 3.87 \mathrm{~km}$, the effective sampled area was $1,100 \pm \mathrm{SD} 455 \mathrm{~km}^{2}$ and jaguar density was estimated at $1.28 \pm \mathrm{SE} 0.62$ per $100 \mathrm{~km}^{2}$.

\section{Discussion}

Although CAPTURE selected the behavioural model $\mathrm{M}_{\mathrm{b}}$ as the best population estimator, with probability of recapture being higher than that of initial capture, we do not think there was a 'trap-happy' response to our cameras as there was no bait or lure associated with the traps. Cameratrapping jaguars in the Brazilian Pantanal, Soisalo \& Cavalcanti (2006) also found model $\mathrm{M}_{\mathrm{b}}$ to be the most appropriate and attributed this to the fact that their camera traps were set in places regularly used by jaguars. Similarly, the high recapture rates we observed probably resulted from our camera traps being set along roads. As reliability of model choice in CAPTURE can be weak (Stanley \& Burnham, 1998), we believe that choice of model $M_{b}$ is probably an artefact of the small sample size rather than an indication of a behavioural response by the animals to trapping. In territorial mammals individual heterogeneity in capture probability is likely to occur (Karanth \& Nichols, 1998). As $M_{b}$ tends to underestimate population size if other sources of variation in capture probability are present 
(Otis et al., 1978) we consider our abundance estimate conservative.

The abundance of prey species is a determining factor for the abundance of large predators (Schaller, 1972; Karanth \& Nichols, 1998; Karanth et al., 2004), with medium- to large-sized mammals being the preferred prey of jaguars (López González \& Miller, 2002). In the Pantanal high prey availability may be responsible for the high jaguar densities of 6.7 individuals $100 \mathrm{~km}^{-2}$ (Soisalo \& Cavalcanti, 2006) compared to other areas in Brazil (Table 2). Semi-arid systems such as caatinga are characterized by a low mean annual precipitation that results in low plant productivity (Davidson, 1977) and herbivore abundance (Chase et al., 2000). Medium- to large-sized jaguar prey species in the Orders Perissodactyla and Artiodactyla, such as tapirs Tapirus terrestris, deer Mazama spp. and peccaries Tayassu spp., are scarce in the caatinga, probably because of the low productivity and recent hunting pressure. These species are now only relict populations (Oliveira et al., 2003). In addition, the caatinga is characterized by small-scale subsistence farming with low agricultural production (MMA, 2007). The rural population is poor and poaching is common (Leal et al., 2005), providing access both to a protein source and to money from selling excess game (Graffin, 2007). Depletion of the prey base may thus be potentially limiting the jaguar population.

Previous studies, based on relative abundance indexes (Wolff, 2001), have suggested that densities of jaguars and of medium- to large-sized prey species such as deer, peccaries and giant anteaters Myrmecophaga tridactyla are low in the Serra da Capivara National Park (SMAPR, 1994; Wolff, 2001). Our estimate of jaguar density is thus higher than we expected. Our findings could indicate an adaptability of jaguars to feed on more readily available, smaller prey species in the caatinga. The small armadillos (Dasypus sp. and others) are part of the jaguar's diet in the Park (Olmos, 1993), and have also been reported to constitute part of the species' diet in the Atlantic Forest of Brazil (Garla et al., 2001). Since 2000 a strong and effective patrolling system has been implemented in the Park, with increased control of poaching. This may have helped the recovery of some populations of medium- to large-sized prey species. The park-wide system of artificial waterholes may also be benefiting these species. Additional studies of jaguar diet and prey availability, which we are currently conducting, will help to clarify this situation.

As our effective sampled area of $524 \mathrm{~km}^{2}$ covered nearly half of the Serra da Capivara National Park and was primarily composed of high shrubby caatinga, the predominant vegetation type (Fig. 1), we extrapolated our estimate of jaguar density to the entire Park. This extrapolation indicates that the Park may hold up to 34 adult jaguars. These results suggest that some areas in the caatinga still have the potential to sustain important jaguar populations. However, the situation in this well-protected Park probably does not reflect the reality for the other, mostly unprotected, areas of this biome: medium- to largesized prey species, which generally comprise the bulk of the jaguar's diet (López González \& Miller, 2002), are naturally sparse in this semi-arid environment (Oliveira et al., 2003) and their populations are further depleted by poaching (Leal et al., 2005). In addition, jaguar habitat is extremely fragmented (Castelletti et al., 2004) and there is a lack of information on the distribution, ecology and status of the caatinga jaguar (Oliveira, 2002). The work presented here is part of an ongoing study of these topics in Serra da Capivara National Park and the nearby Serra das Confusões National Park. Our results have been provided to the Park authorities for consideration in park management plans. However, similar studies in additional areas are also needed for an improved understanding of the status of the jaguar and to provide data for conservation plans for this species in the caatinga.

\section{Acknowledgements}

We appreciate the support provided by the Fundação Museu do Homem Americano and the park administration of Instituto Brasileiro do Meio Ambiente, which made this study possible. The study was funded by the Jaguar Conservation Fund (JCF), Oregon Zoo's Future for Wildlife Grants Program, University of Brasilia, Idea Wild, the

TABle 2 Jaguar densities in Brazil estimated using camera-trap data in combination with mark-recapture models.

\begin{tabular}{|c|c|c|c|}
\hline Biome & $\begin{array}{l}\text { Density } \pm \mathrm{SE} \\
\text { (individuals } 100 \mathrm{~km}^{-2} \text { ) }\end{array}$ & $\begin{array}{l}\text { Effectively sampled } \\
\text { area using the half of the } \\
\text { mean maximum distance } \\
\text { moved buffer }\left(\mathrm{km}^{2}\right)\end{array}$ & Reference \\
\hline Cerrado & $2.00^{1}$ & $500^{2}$ & Silveira (2004) \\
\hline Atlantic Forest (Brazil-Argentina border) & $0.87 \pm 0.3 / 1.46 \pm 0.34$ & $576.61 / 958.16$ & Paviolo et al. (2008) \\
\hline Atlantic Forest & $2.22 \pm 1.33$ & 300 & Cullen et al. (2005) \\
\hline Pantanal & $10.3 \pm 1.53$ & 360 & Soisalo \& Cavalcanti (2006) \\
\hline Caatinga & $2.67 \pm 1.06$ & 524 & This study \\
\hline
\end{tabular}

\footnotetext{
${ }^{1}$ No SE was calculated for density

${ }^{2}$ Estimated using a mean home range-based buffer
} 
Memphis Zoo and the Woodland Park Zoo. We thank Barbara Zimbres, Debora Schistek, Eliot Cohen and Marina Carvalho for field assistance. A scholarship grant to SA was provided by Conselho Nacional de Desenvolvimento Científico e Tecnológico (CNPq) and for RS by the German Academic Exchange Service. This study is part of the JCF jaguar population monitoring programme in Brazil. JM-F also received financial support from CNPq.

\section{References}

Capobianco, J.P.R. (2002) Artigo sobre os biomas Brasileiros. In Meio Ambiente Brasil: avanços e obstáculos pós-Rio-92 (eds A. Camargo, J.P.R. Capobianco \& J.A.P. Oliveira), pp. 117-155. Estação Liberdade/Instituto Socioambiental/ Fundação Getúlio Vargas, São Paulo, Brazil.

Caso, A., Lopez-Gonzalez, C., Payan, E., Eizirik, E., de Oliveira, T., Leite-Pitman, R. et al. (2008) Panthera onca. In IUCN Red List of Threatened Species v. 2009.1. Http://www. iucnredlist.org [accessed 28 August 2009].

Castelletti, C.H.M., Silva, J.M.C., Tabarelli, M. \& Santos, A.M.M. (2004) Quanto ainda resta da caatinga? Uma estimativa preliminar. In Biodiversidade da Caatinga: áreas e ações prioritárias para a conservação (eds J.M.C. Silva, M. Tabarelli, M. Fonseca \& L. Lins), pp. 91-10o. Ministério do Meio Ambiente, Brasília, Brazil.

Chase, J.M., Downing, A.L. \& Shurin, J.B. (2000) The effects of productivity, herbivory, and plant species turnover in grassland food webs. Ecology, 81, 2485-2497.

Cullen, Jr, L., Sana, D., Abreu, K.C. \& Nava, A.F.D. (2005) Jaguars as landscape detectives for the upper Paraná river corridor, Brazil. Natureza e Conservação, 3, 124-146.

Davidson, D.W. (1977) Species diversity and community organization in desert seed-eating ants. Ecology, 58, 711-724.

Emperaire, L. (1984) A região da Serra da Capivara (Sudeste do Piauí) e sua vegetação. Brasil Florestal, 14, 5-21.

Fonseca, G.A.B. \& Robinson, J.G. (1990) Forest size and structure: competitive and predatory effects on small mammal communities. Biological Conservation, 53, 265-294.

Garla, R.C., Setz, E.Z. \& Gobi, N. (2001) Jaguar (Panthera onca) food habits in Atlantic rain forest of south-eastern Brazil. Biotropica, 33, 691-696.

Graffin, R. (2007) Avaliação dos impactos antrôpicos no Parque Nacional Serra da Capivara Piauí-Brasil. MSc thesis, Institut National Agronomique Paris-Grignon/Universté Paris VII Denis Diderot, Paris, France.

KaRANTH, K.U. \& Nichols, J.D. (1998) Estimation of tiger densities in India using photographic captures and recaptures. Ecology, 79, 2852-2862.

Karanth, K.U., Nichols, J.D., Samba Kumar, N., Link, W.A. \& Hines, J.E. (2004) Tigers and their prey: predicting carnivore densities from prey abundance. Proceedings of the National Academy of Sciences, 101, 4854-4858.

Leal, I.R., Da Silva, J.M.C., Tabarelli, M. \& Lacher, Jr, T. (2005) Changing the course of biodiversity conservation in the caatinga of north-eastern Brazil. Conservation Biology, 19, 701-706.

López González, C. \& Miller, B. (2002) Do jaguars (Panthera onca) depend on large prey? Western North American Naturalist, 62, 218-222.

Maffei, L., Cuéllar, E. \& Noss, A. (2004) One thousand jaguars (Panthera onca) in Bolivia's Chaco? Camera trapping in the
Kaa-Iya National Park. Journal of Zoology, London, 262, 295-304.

Miller, B., Dugelby, B., Foreman, D., Martinez del Rio, C., Noss, R., Phillips, M. et al. (2001) The importance of large carnivores to healthy ecosystems. Endangered Species Update, 18, 202-210.

MMA (Ministério do MeIo Ambiente) (2005) Repartição da flora lenhosa no domínio da caatinga. In Análise das variações da biodiversidade do bioma caatinga: suporte a estratégias regionais de conservação (organizers F.S. de Araújo, M.J.N. Rodal \& M.R.V. Barbosa), pp. 19. Ministério do Meio Ambiente, Brasília, Brazil.

MMA (Ministério do Meio Ambiente) (2007) PROBIO-Projeto de Conservação e Utilização Sustentável da Diversidade Biológica Brasileira. Subprojeto: Levantamento da Cobertura Vegetal e do uso do Solo do Bioma Caatinga. Http://mapas.mma.gov.br/mapas/ aplic/probio/datadownload.htm [accessed 10 June 2008].

Oliveira, J.A., Gonçalves, P.R. \& Bonvicino, C.R. (2003) Mamíferos da caatinga. In Ecologia e Conservação da Caatinga (eds R.L. Leal, M. Tabarelli \& J.M.C. Silva), pp. 275-336. Editora Universitária da UFPE, Recife, Brazil.

Oliveira, T. DE (2002) Evaluación del estado de conservación del jaguar en el este de la Amazonía y noreste de Brasil. In El Jaguar en el Nuevo Milenio (eds R.A. Medellín, C. Equihua, C.L.B. Chetkiewitcz, P.G. Crawshaw, Jr, A. Rabinowitz, K.H. Redford et al.), pp. 419-436. Ediciones Científicas Universitárias, Universidad Nacional Autónoma de México and Wildlife Conservation Society, Mexico.

Olmos, F. (1993) Notes on food habits of Brazilian "caatinga" carnivores. Mammalia, 57, 126-130.

Otis, D.L., Burnham, K.P., White, G.C. \& Anderson, D.R. (1978) Statistical inference from capture data on closed populations. Wildlife Monographs, 62, 1-135.

Paviolo, A., De Angelo, D.E., Di Blanco, Y.E \& Di Bettiti, M.S. (2008) Jaguar Panthera onca population decline in the Upper Paraná Atlantic Forest of Argentina and Brazil. Oryx, 42, 554-561.

Rexstad, E. \& BURnham, K.P. (1991) User's Guide for Interactive Program CAPTURE. Colorado Cooperative Fish \& Wildlife Research Unit, Colorado State University, Fort Collins, USA.

Ripple, W.J. \& Beschta, R.L. (2006) Linking a cougar decline, trophic cascade, and catastrophic regime shift in Zion National Park. Biological Conservation, 133, 397-408.

Sanderson, E., Redford, K.H., Chetkiewicz, C.B., Medellín, R., Rabinowitz, A., Robinson, J.G. \& Taber, A.B. (2002) Planning to save a species: the jaguar as a model. Conservation Biology, 16, 58-72.

Schaller, G.B. (1972) The Serengeti Lion: A Study of Predator Prey Relations. University of Chicago Press, Chicago, USA.

SMAPR (Secretaria do Meio Ambiente da Presidência da República) (1994) Plano de Manejo Parque Nacional Serra da Capivara. SMAPR, Brasília, Brazil.

Seymour, K.L. (1989) Panthera onca. Mammalian Species, 340, 1-9. Silveira, L. (2004) Ecologia comparada e conservação da onçapintada (Panthera onca) e onça-parda (Puma concolor), no Cerrado e Pantanal. PhD thesis, University of Brasília, Brasília, Brazil.

SilveirA, L. \& JÁcomo, A.T.A. (2002) Conservación del jaguar en el centro del Cerrado de Brasil. In El Jaguar en el Nuevo Milenio (eds R.A. Medellín, C. Equihua, C.L.B. Chetkiewitcz, P.G. Crawshaw, Jr, A. Rabinowitz, K.H. Redford et al.), pp. 437-45o. Ediciones Científicas Universitárias, Universidad Nacional Autónoma de México and Wildlife Conservation Society, Mexico.

Silver, S. (2004) Assessing Jaguar Abundance Using Remotely Triggered Cameras. Wildlife Conservation Society, New York, USA. 
Silver, S., Ostro, L., Marsh, L., Maffei, L., Noss, A., Kelly, M. et al. (2004) The use of camera traps for estimating jaguar Panthera onca abundance and density using capture/recapture analysis. Oryx, 38, 148-154.

Soisalo, M. \& Cavalcanti, S. (2006) Estimating the density of a jaguar population in the Brazilian Pantanal using cameratraps and capture-recapture sampling in combination with GPS radio-telemetry. Biological Conservation, 25, 487-496.

Stanley, T.R. \& Burnham, K.P. (1998) Estimator selection for closed-population capture-recapture. Journal of Agricultural, Biological, and Environmental Statistics, 3, 131-150.

TERBorgh, J. (1988) The big things that run the world-a sequel to E.O. Wilson. Conservation Biology, 2, 402-405.

Terborgh, J., Estes, J.A., Paquet, P.C., Ralls, K., Boyd-Heger, D., Miller, B. \& Noss, R. (1999) Role of top carnivores in regulating terrestrial ecosystems. In Continental Conservation: Design and Management Principles for Long-Term, Regional Conservation Networks (eds M.E. Soulé \& J. Terborgh), pp. 39-64. Island Press, Washington, DC, USA.

Terborgh, J., Lopez, L., Tello, J., Yu, D. \& Bruni, A.R. (1997) Transitory states in relaxing land bridge islands. In Tropical Forest Remnants: Ecology, Management, and Conservation of Fragmented Communities (eds W.F. Laurance \& R.O. Bierregaard, Jr), pp. 256-274. University of Chicago Press, Chicago, USA.

Wallace, R.B., Gomez, H., Ayala, G. \& Espinoza, F. (2003) Camera trapping for jaguar (Panthera onca) in the Tuichi Valley, Bolivia. Mastozoologia Neotropical/Journal of Neotropical Mammals, 10, 133-139.

Weber, W. \& Rabinowitz, A. (1996) A global perspective for large carnivore conservation. Conservation Biology, 10, 1046-1054.
White, G.C., Anderson, D.R., Burnham, K.P. \& Otis, D.L. (1982) Capture-Recapture and Removal Methods for Sampling Closed Populations. Los Alamos National Laboratory, Los Alamos, USA.

Wilson, K.R. \& ANDERSON, D.R. (1985) Evaluation of two density estimators of small mammal population size. Journal of Mammalogy, 66, 13-21.

W olf F, F. (2001) Vertebrate ecology in caatinga: A. Distribution of wildlife in relation to water. B. Diet of pumas (P. concolor) and relative abundance of felids. MSc thesis, University of Missouri, St. Louis, USA.

\section{Biographical sketches}

Leandro Silveira is interested in large-scale predator conservation, especially of the jaguar, and also researches methods for reducing predator/rancher conflict. АNAн T.A. ЈА́сомо focuses on large mammal conservation and management in human-dominated landscapes. Samuel Astete studies jaguar ecology in the caatinga to improve the knowledge of this and other species in this little studied biome. Rahel Sollmann focuses on jaguar ecology and conservation status in the fragmented landscape of the central Brazilian cerrado. Natélia M. TôrRes uses ecological niche modelling to evaluate the jaguar's distribution under current and future climate scenarios to identify priority areas for jaguar conservation. MA R I ANA M. FURTADO is investigating the epidemiological relationship between jaguars and domestic animals in Brazil to understand the role diseases play in jaguar conservation. JADER MARINHO-FILHO focuses his work on mammal zoology, ecology and conservation. 